Ventura G, Jeha S, Horwitz LJ, Trujillo JM, Gillis S, Hettelman WN, Gutterman JU 1988 Stimulation of myelopoiesis in patients with aplastic anemia by recombinant human granulocyte-macrophage colony-stimulating factor. N Engl J Med 319:1628-1634

64. Antin JH, Smith BR, Holmes W, Rosenthal DS 1988 Phase I/II study of recombinant human granulocyte-macrophage colony stimulating factor in aplastic anemia and myelodysplastic syndrome. Blood 72:705-713

65. Guinan EC, Sieff CA, Oette DH, Nathan DG 1989 Granulocyte-macrophage colony-stimulating factor (GM-CSF) in aplastic anemia. Pediatr Res 25 (part II): $151 \mathrm{a}$ (abstr)

66. Donahue RE, Seehra J, Metzger M, Lefebre D, Rock B, Carbone S, Nathan DG, Garnick M, Sehgal PK, Laston D, LaVillie E, McCoy J, Schendel PF, Norton C, Turner K, Yang Y-C, Clark SC 1988 Human IL-3 and GM-CSF act synergistically in stimulating hematopoiesis in primates. Science 241:1820-1823

\title{
Announcement
}

\section{Meeting Announcement}

The Society for Behavioral Pediatrics will conduct its 8th Annual Scientific Meeting on September 16-17, 1990 at the Westin Hotel in Denver, CO. The theme of this meeting will be "Behavioral Pediatrics and Education: A Vital Interface." The 1990 SBP Lectureship Address will be delivered by Bettye M. Caldwell, Ph.D. For further information and registration forms, please contact Ms. Noreen Spota at (215) 248-9168. 